\title{
Penetrasi Nelayan Tradisional Panaikang 1955-1970
}

\author{
Haerianty Rezki Sani, Ahmadin, Amirullah \\ Pendidikan Sejarah FIS UNM \\ haerianty.r.s@gmail.com
}

\begin{abstract}
Abstrak
Tulisan ini mengkaji tentang penetrasi nelayan tradisional di Desa Panaikang Kecamatan Sinjai Timur Kabupaten Sinjai (1955-1970). Hasil penelitian menunjukkan bahwa pada 1955 mulai marak aktivitas nelayan mencari ikan di laut. Mereka hidup berkelompok menurut daerah tempat mereka mencari nafkah. Nelayan tradisional di Desa Panaikang dijuluki sebagai pa'panja karena alat tangkap yang digunakan berupa payang (panja). Awalnya, wilayah penangkapan nelayan tradisional tidak jauh dari garis pantai. Seiring perkembangannya merambah ke wilayah operasional yang cukup jauh yakni ke Tanjung Pandang dan Bangka. Perjalanan ditempuh selama 1 bulan dengan petunjuk kompas, posisi matahari dan bulan. Perahu yang digunakan seperti perahu Biruang, perahu Pagatang dan Soppe' Bajo yang digerakkan dengan dayung dan layar. Nelayan terdiri dari 8-12 orang pada tiap perahu. Terdapat pula komponen kerja antar nelayan serta adanya klasifikasi nelayan yakni punggawa, pemilik payang (panja), dan sawi yang terbentuk atas dasar kekeluargaan. Orientasi penangkapan ikan masih bersifat subsisten. Kondisi ekonomi nelayan di Desa Panaikang saat itu sejahtera, dan ini dirasakan oleh punggawa. Hal ini dapat dilihat dari adanya sistem bagi hasil yakni 50\% untuk punggawa, pemilik panja dan sawi mendapat 25\% bagian. Terdapat sebuah tradisi selamatan dengan membuat sulo fesse saat hendak melaut yang dianggap berpengaruh terhadap hasil tangkapan. Penelitian ini menggunakan metode penelitian sejarah, yakni: heuristic, kritik sumber, interpretasi dan historiografi . Metode pengumpulan data dilakukan dengan cara penelitian lapangan terdiri dari wawancara (punggawa, sawi dan istri nelayan) dan mengumpulkan sumber arsip (arsip Sinjai, dokumen dari kantor desa dan nelayan) serta literatur-literatur yang berhubungan.
\end{abstract}

\section{Kata Kunci : Nelayan, Tradisional, Panaikang}

\begin{abstract}
This paper discusses about the traditional fishermans penetration in the village of Panaikang subdistrict of Sinjai Timur the regency of Sinjai (1955-1970). The result of research indicates that in 1955 the people began to looking for fish in the sea. They live in groups according to the area where they make a living. The traditional fisherman in the Panaikang village were referred to as the papanja because of the used of the payang (panja). Originally, traditional fishing grounds were not far from the shoreline. As it progresses to the operational terrority far enough to the Tanjung Pandang and Bangka. A single months journey with compass instructions, the position of the sun and the moon. A boat that used a Biruang boat, pagatang boat, and soppe' bajo with oars and sails. Fishermen of 8-12 people on each boat. There are also components of a fishermans work and as well as the class of the fishermen, had payang (panja), and the sawi, who were founded on the basis of family activities. The fishing orientation is still subsisten. The economic conditions of the fishermen in the village of Panaikang were the prosperous, and this was felt by punggawa. This can be seen from the existence of a system of $50 \%$ for punggawa, the have panja and sawi gets a $25 \%$. There were a traditional of survival by making sulo fesse when going to sea, it was a matter of catch. This study used the method
\end{abstract}


historical research, namely: heuristic, criticism of the source, interpretation and historiography. Data collection methods are done by how a field research is made up of interviews (punggawa, sawi and the fishermens wife) and collect the source of the archives (Sinjai archives, documents from the village and fishing offices) and the literature related.

\section{Keyword : Fisherman, Traditional, Panaikang}

\section{A. Pendahuluan}

Penetrasi menurut Kamus Besar

Bahasa Indonesia diartikan sebagai suatu penembusan, penerobosan, atau perembesan.( Tim Penyusun Pusat Kamus, 2007) Sedangkan nelayan tradisional ialah orang yang pekerjaannnya menangkap ikan menggunakan perahu dan alat tangkap yang sederhana (tradisional). Dengan keterbatasan perahu maupun alat tangkap, maka jangkauan wilayah penangkapan menjadi terbatas dan biasa hanya berjarah 6 mil dari garis pantai.(Endang Retnowati, 2011) Dengan demikian, penetrasi nelayan tradisional ialah suatu terobosan yang dilakukan oleh nelayan tradisional dengan menjajaki wilayah operasional yang cukup jauh dari pesisir pantai meskipun hanya menggunakan alat yang masih sederhana.

Kabupaten Sinjai adalah salah satu dari 24 kabupaten/kota dalam wilayah Provinsi Sulawesi Selatan.(BPS, Kabupaten Sinjai Dalam Angka, 2015). Hingga saat ini Sinjai dikenal sebagai kabupaten penghasil ikan. Hal ini ditandai dengan adanya Pelabuhan Larea-rea dan Tempat Pelelangan Ikan (TPI) di Lappa, Kecamatan Sinjai Utara. Terlepas dari itu, terdapat salah satu desa yakni Desa Panaikang yang warganya mayoritas memilih pekerjaan sebagai nelayan namun sangat jarang ditilik akan budaya baharinya. Terutama kehidupan nelayan sebelum terkena dampak modernisasi.

Nelayan di Desa Panaikang berbeda dengan nelayan pada umumnya. Mereka telah melakukan penetrasiatauterobosan yang tidak dilakukan oleh nelayan tradisional lainnya. Adapun bentuk terobosannya yani nelayan ini yang awalnya mencari ikan di pesisir pantai lambat laun merambah ke perairan yang jaraknya cukup jauh dari Kabupaten Sinjai bahkan sampai ke Tanjung Pandang dan Bangka. Adapun waktu yang digunakan untuk mencari ikan berkisar 1-6 bulan lamanya, bahkan mereka menetap di daerah tersebut dalam jangka waktu yang cukup lama. Selain itu, hal unik dari nelayan di Desa Panaikang ialah bentuk perahunya yang cukup panjang hingga 10 meter seperti perahu Biruang, perahu Pagatang dan Soppe' Bajo.Adanya perubahan perahu dari tahun ke tahun ini akibat lokasi penangkapan ikan yang semakin jauh.

Skripsi yang ditulis oleh Muhammad Asrar tahun 2016 dengan Judul Nelayan Papekang di Bonto Kamase (1980-2000). Tulisan ini membahas mengenai latar belakang kehidupan nelayan papekang di Bonto Kamase, perkembangan dari segialat tangkap dan perahuserta dampak yang timbul dalam kehidupan sosial ekonomi masyarakat Bonto Kamase. Sejak 1960 nelayan di Bonto kamase di juluki sebagai nelayan papkekang karena alat tangkap yang digunakan ialah pancing. Selain itu, perkembangan dari segi perahu antara lain mulai dari penggunaan sampan 1960, lalu perahu bercadik (soppek) 1975.

Perbedaan kajiannya terletak pada alat tangkap yang digunakan. Nelayan tradisional di desa Panaikang menggunakan payang (panja) sehingga di juluki sebagai nelayan papanja. Perkembangan dari segi perahunya pun tidak sama, baik dari ukuran serta muatan. Nelayan papekang pada masa tradisional menggunakan sampan 1960, lalu perahu bercadik (Soppek) 1975 yang ukurannya hingga 3 meter, kapasitas hanya 2 orang saja. Sedangkan nelayan tradisional di desa panaikang menggunakan perahu yang panjangnya hingga 10 meter dengan kapasitas 10-12 orang. Selain itu, terdapat 
tradisi selamatan yang dilakukan oleh nelayan saat hendak melaut.

Karya ilmiah lainnya dalam bentuk jurnal yang ditulis oleh Tri Joko Sri Haryono tahun 2005 dengan Judul Strategi Kelangsungan Hidup Nelayan. Jurnal ini membahas tentang strategi nelayan dalam mempertahankan kelangsungan hidup. Pola penangkapan ikan nelayan tradisional di desa Randuputih menggunakan alat tangkap yang sederhana berupa jaring. Nelayan menggunakan perahu yang kecil berkapasitas 2 orang. Wilayah operasional nelayan masih terbatas di sekitar pesisir pantai. Selain itu ketergantungan terhadap alam (musim) juga sangat tinggi, sehingga tidak setiap saat nelayan bias melaut, terutama pada musim ombak. Akibatnya nelayan melakukan pekerjaan sampingan misalnya sebagai pedagang ikan, buruh tani, buruh bangunan dan pekerja serabutan.

Hal pembeda dengan nelayan tradisional yang ada di desa panaikang, sejak 1955 menggunakan alat tangkap berupa payang (panja). Perahu yang digunakan berukuran panjang dan memuat hingga 12 orang. Wilayah operasional awalnya dekat dari pesisir pantai namun lambat laun merambah jauh ke wilayah tanjung pandang dan Bangka. Nelayan di Desa Panaikang menjadikan kegiatan menangkap ikan di laut sebagai pekerjaan pokok untuk menghidupi keluarganya.

Melihat dinamika kehidupan nelayan tradisional di Desa Panaikang dari tahun 1955-1970, meskipun telah menghadapi berbagai kendala dalam menstabilkan perekonomiannya. Namun itu tidaklah menjadi penghambat bagi nelayan di Desa Panaikang untuk tetap menggeluti pekerjaan sebagai nelayan.

Oleh karena itu, penulis tertarik untuk mengkaji tentang Penetrasi Nelayan Tradisional Panaikang (1955-1970). Batasan temperol yang dikaji pada jurnal ini yakni 1955-1970. Dimana tahun awal keberadaan nelayan tradisional di Desa Paikang yakni sejak tahun 1955 lalu pada 1970 sudah terkena dampak modernisasi. Batasan spasial jurnal ini di Desa Panaikang
Kecamatan Sinjai Timur Kabupaten Sinjai.Batasan tematik kajian tulisan ini yakni Sejarah Maritim.

\section{B. Metode Penelitian}

Metode penelitian yang digunakan ialah kualitatif. Metode ini sering digunakan dalam ilmu sejarah dan ilmu sosial lainnya dengan tujuan untuk menemukan suatu hal yang unik dan mampu mengungkapkan peristiwa yang telah terjadi di masa lampau (Sugeng Priyadi, 2012)

Metode penelitian ini juga merupakan metode penelitian sejarah yang bersifat deskriptif, menginterpretasikan terkait nelayan di Desa Panaikang Kecamatan Sinjai Timur Kabupaten Sinjai. Penelitian ini di jelaskan tentang bagaimana kehidupan awal mula keberadaan nelayan tradisional, perkembangan nelayan tradisional, dan bagaimana kehidupan sosial, ekonomi, dan budaya nelayan tradisional di Desa Panaikang.

Dengan adanya metode sejarah, maka penelitian yang dilakukan akan lebih mudah dipahami oleh peneliti itu sendiri. Sebagaimana yang diungkapkan Kuntowijoyo terdapat lima tahapan penelitian sejarah yaitu, pemilihan topik, pengumpulan sumber, verifikasi (kritik sejarah, keabsahan sumber), interpretasi: analisis dan sintesis, dan penulisan (Kuntowijoyo, 2005)

\section{Heuristik}

Tahap ini merupakan tahap mengumpulkan sumber-sumber sejarah yang relevan dengan topik penelitian. Kegiatan ini diarahkan pada pencarian dan pengumpulan sumber yang berkaitan dengan masalah atau objek yang dikaji, yaitu "Sinergitas Nelayan Ulung di Desa Panaikang 1955-1970”. Dalam melakukan pengumpulan sumber ditempuh melalui dua cara yaitu penelitian pustaka dan penelitian lapangan.

\section{a. Penelitian Pustaka}

Studi pustaka merupakan salah satu langkah penting dalam penelitian sejarah. Dalam studi pustaka ini akan dilakukan studi terhadap sejumlah bahan pustaka, 
baik yang berupa arsip, buku, dan hasil penelitian lainnya yang memiliki kaitan dengan topik penelitian ini. Bahan-bahan pustaka tersebut penulis peroleh dari Badan Pusat Statistik Kabupaten Sinjai, dan Kantor Desa Panaikang. Adapun sumber dan referensi yang ditemukan, terkait tentang nelayan yaitu buku yang berjudul Nelayan Tradisional dan Modernisasi yang ditulis oleh Ahmadin (2009), merupakan sumber untuk memahami bagaimana pola orientasi nelayan tradisional, serta kehidupan sosial, ekonomi, dan budaya nelayan. Buku yang berjudul Agama Nelayan yang ditulis oleh Arifuddin Ismail (2012). Buku Akar Kemiskinan Nelayan yang ditulis oleh Kusnadi (2003).

\section{b. Penelitian lapangan}

Penelitian ini dilakukan dengan jalan mengumpulkan sumber secara langsung di lapangan atau lokasi terkait judul tersebut. Dalam hal ini peneliti melakukan penelitian secara langsung di Desa Panaikang Kecamatan Sinjai Timur Kabupaten Sinjai menggunakan metode wawancara. Hasil wawancara ini dapat direkam dan dicatat untuk selanjutnya diperbaiki pada saat penyusunan hasil penelitian. Selain itu, peneliti juga menggunakan dokumentasi penelitian. Hal tersebut dilakukan agar data yang diperoleh peneliti sifatnya objektif dan dapat dipertanggungjawabkan. Adapun daftar informan yang di peneliti wawancarai ialah H. Tulisi (pemilik kapal), Mustaming (pemilik kapal), dan Sakka (istri nelayan). Kendala selama penelitian yakni terbatasnya informasi mengenai nelayan tradisional dikarenakan masyarakat telah beralih menjadi nelayan modern.

\section{Kritik}

Setelah memperoleh sumber-sumber yang memadai, langkah selanjutnya adalah menilai sumber tersebut untuk menyeleksi dan menguji kebenaran dan keabsahan suatu sumber, guna mendapatkan data yang otentik. Data berupa hasil wawancara dari informan serta dokumen dari kantor desa harus disaring secara kritis, terutama terhadap sumber-sumber pertama, agar terjaring fakta yang menjadi pilihannya.

\section{Interpretasi}

Tahapan ini merupakan langkah setelah kritik sumber. Sumber-sumber sejarah yang telah didapatkan sifatnya masih bisu. Oleh karena itu, perlu ditafsirkan oleh peneliti. Interpretasi dapat dilakukan dengan cara membandingkan data yang telah diperoleh dengan data yang telah ada sebelumnya sehinga seorang peneliti mampu menyusun fakta-fakta sejarah yang dapat dibuktikan kebenarannya.

\section{Historiografi}

Dalam kaitannya dengan historiografi, yaitu proses penulisan sejarah banyak aspek yang terkait didalamnya. Menurut Hexter, proses pengumpulan bukti-bukti sejarah, pengeditan sumber sejarah, penggunaan pemikiran dan imajinasi sejarah, dan sebagainya merupakan suatu proses yang tidak dapat dipisahkan dari historiografi (Hariyono, 1995)

Pada tahap peneliti mencoba untuk menggambarkan hasil penelitiannya. Dalam hal ini pada penelitian tentang Penetrasi Nelayan Tradisional Panaikang 1955-1970. Peneliti mencoba untuk menggambarkan bagaimana awal mula keberadaan nelayan tradisional, perkembangan nelayan tradisional serta kehidupan sosial, ekonomi, dan budaya nelayan itu sendiri.

\section{Tinjauan Penelitian \\ 1. Kondisi Geografis}

Kondisi alam sangat berpengaruh dalam kehidupan manusia. Pengertian keadaan geografis yang dimaksudkan seperti yang dikemukakan Polak bahwa keadaan geografis adalah segala kondisi yang tersedia oleh alam untuk manusia.(Mayor Polak, 1976) Khususnya memperhatikan kombinasi kondisi alam. Demikian pula geografisnya meliputi tanah dan segala keadaan di dalamnya.

Keadaan geografis sangatlah penting diketahui untuk menjadikan suatu wilayah sebagai objek penelitian. Mempelajari lokasi berlangsungnya suatu peristiwa merupakan keharusan bagi seseorang yang telah mengungkapkan sejarah disuatu daerah. Sebagaimana diungkapkan pula 
Tamburaka bahwa peranan sejarah ditentukan oleh faktor-faktor geografis.(Rustam Tamburaka, 1999) Dengan ini jelas dapat dikatakan bahwa bumi tidak ada, sudah tentu tidak ada sejarahnya.

Desa Panaikang Kecamatan Sinjai Timur Kabupaten Sinjai merupakan bagian integral dari sistem perwilayahan Kecamatan Sinjai Timur. Berdasar letak geografis wilayah, Desa Panaikang berada antara 5 11' 70.000" LS dan 120 14'30.000" BT.(Profil Desa Panaikang, 2017) Desa ini terletak di daerah dataran rendah yakni wilayah pantai.

Desa Panaikang terdiri dari 4 wilayah dusun yakni Dusun Baringeng, Dusun Bangko, Dusun Macini dan Dusun Buakang. Iklim di Desa Panaikang cenderung sama dengan wilayah lain yang ada di Kabupaten Sinjai. Pada umumnya dipengaruhi oleh Angin Muson Timur dan Angin Muson Barat Laut. Angin Muson Timur bertiup pada bulan februari hingga juni sehingga mengakibatkan terjadinya musim kemarau, sedangkan Angin Muson Barat Laut bertiup dari bulan agustus hingga bulan januari yang di mana menimbulkan musim penghujan. Iklim di Desa Panaikang Kecamatan Sinjai Timur Kabupaten Sinjai, dikenal dengan dua musim yakni musim hujan dan musim kemarau. (Profil Desa Panaikang, 2017).

\section{Kondisi Demografi}

Demografi mempelajari penduduk (suatu wilayah) terutama mengenai jumlah, struktur (komposisi penduduk) dan perkembangannya (perubahannya).(Ida Bagoes Mantra, 2000) Jumlah penduduk Desa Panaikang pada tahun 2015 ada sebanyak 483 Kepala Keluarga (KK) dengan jumlah penduduk 1.831 jiwa, yang terdiri dari 834 laki-laki dan 997 perempuan(Profil Desa Panaikang, 2017). Rasio jumlah penduduk berjenis kelamin perempuan lebih bnayak dari penduduk yang berjenis kelamin laki-laki. Sehingga setiap tahunnya penduduk yang mendiami Desa Panaikang mengalami peningkatan. Peningkatan tersebut pada dasarnya disebabkan oleh adanya jumlah kelahiran yang meningkat dalam penduduk. Penduduk ialah orang yang tinggal pada suatu daerah dan merupakan salah satu elemen penting yang memiliki pengaruh kuat terhadap perkembangan daerah tersebut .

Pada tahun 1960 Desa Panaikang dihuni oleh etnik Bugis, sehingga bahasa yang digunakanpun masih menggunakan bahasa asli setempat atau bahasa Bugis saat melakukan interaksi dengan masyarakat sekitar, selain itu masyarakat yang berada di Desa Panaikang juga masih memegang teguh nilai-nilai kebersamaan, contohnya adalah nilai gotong royong. Sikap kegotong royongan masyarakat dapat dilihat ketika mereka sedang membangun rumah, di mana warga atau masyarakat setempat bersama-sama saling bantu membantu dalam membangun rumah khususnya adalah rumah panggung, saling membantu pula saat menanam padi di sawah dengan tanpa dibayar sama sekali dan hanya dijamu makanan setelah rangka bangunan telah berdiri. Selain itu masyarakat saling membantu jika ada acara selamatan dan berbondong-bondong mengantar para nelayan yang hendak melaut.(Mustaming, 2018)

Dapat pula dikatakan bahwa interasi sosial antar masyarakat yang ada di Desa Panaikang terjalin dengan baik. Kekompakan penduduk dapat dibuktikan dengan saling mendukungnya mereka dalam suka maupun duka, ini dapat dilihat dari salah satunya semagat gotong royong mereka yang telah dipaparkan diatas.

Mata pencaharian suatu masyarakat adalah aspek yang menjadi ukuran pendapatan bagi masyarakat bersangkutan. Semakin baik mata pencaharian seseorang, memungkinkan masyarakat tersebut untuk memperoleh pendapatan yang lebih baik demikian pula sebaliknya, apabila mata pencaharian kurang baik akan mengakibatkan tingkat pendapatan yang diperoleh lebih sedikit. Mata pencaharian pokok penduduk Desa Panaikang ialah Nelayan. Sebagian kecil lainnya bekerja 
sebagai petani, PNS, pengrajin, pedagang, peternak, montir, dokter, tukang kayu serta tukang batu. (Profil Desa Panaikang, 2017)

Dari uraian tersebut dapat dikemukakan bahwa demografi dengan kehidupan nelayan ini saling berkesinambungan. Sebab, kemiskinan nelayan dalam masyarakat dapat pula dipengaruhi dari jumlah orang dalam keluarganya yang mesti di berikan nafkah. Selain itu, kehidupan nelayan dalam mengerjakan sesuatu lebih mudah diselesaikan dengan adanya bantuan dari penduduk lainnya. Sehingga apa yang dikerjakan tidaklah berat, dalam hal ini menjadi lebih mudah teratasi.

\section{Pembahasan}

\section{Awal Mula Nelayan Di Desa Panaikang \\ Letak dan kondisi geografis suatu} daerah sangat mempengaruhi mata pencaharian masyarakat yang mendiami daerah tersebut. Dengan demikian maka keadaan alam merupakan salah satu faktor penunjang bagi kehidupan masyarakat dalam pemenuhan kebutuhan hidupnya. Misalnya suatu daerah memiliki kondisi alam yang cukup potensial seperti dalam bidang penangkapan ikan yang mana nelayan bisa memanfaatkan potensi tersebut dengan adanya proses pemburuan terhadap ikan sebagai biota buruan kemudian diolah agar mampu menunjang kebutuhan sehari-hari bagi masyarakatnya dan diharapkan mendorong suatu kegiatan produksi yang berkelanjutan.(Kusnadi, 2003)

Desa Panaikang terletak di daerah pantai dan potensi sumber daya laut turut menentukan keadaan hidup sebagian masyarakatnya yang bermata pencaharian sebagai nelayan atau pelaut. Profesi sebagai nelayan yang mereka peroleh secara turun temurun dari orang tua mereka dan tidak diketahui pasti sejak kapan masyarakat disana mulai melaut dan menjadikan sumber daya laut sebagai sumber penghidupan masyarakat pesisir. Namun pada 1955 masyarakat mulai mencari ikan di laut untuk memenuhi kebutuhan hidup keluarganya.(Tulisi, 2018) Mereka hidup berkelompok dan membagi diri menurut daerah tempat mereka mencari nafkah atau jenis peralatan yang dipergunakan untuk menangkap ikan.

Faktor lain yang turut menentukan kehidupan ekonomi mereka adalah faktor cuaca yang tidak memungkinkan bagi nelayan untuk melakukan kegiatan menangkap ikan di lautan. Sebab keadaan cuaca sangat berpengaruh terhadap proses operasi penangkapan ikan. Seringkali saat cuaca buruk nelayan tidak melaut untuk menangkap ikan, hal itu tentunya menyebabkan nelayan tidak mendapatkan penghasilan. Dengan demikian keadaan lingkungan alam sekitar merupakan faktor yang sangat berpengaruh dalam kehidupan masyarakat.

Kegiatan nelayan dalam menangkap ikan di laut sebelum terjadinya proses modernisasi pada masyarakat pesisir di Desa Panaikang, pola penangkapan ikan pada saat itu masih bersifat tradisional. Baik dari segia alat tangkap tangkap berupa payang (panja) maupun daerah jangkauan yang masih terbatas sehingga hasil tangkapan tidak begitu maksimal. Hal tersebut disebabkan oleh usaha penangkapan ikan bagi nelayan hanya untuk memenuhi kelangsungan hidup keluarga berada pada tatanan ekonomi yang dikenal sebagai sistem subsistensi.

Berdasarkan studi yang dilakukan oleh Ahmadin, dengan kajian sejarah maritime melalui pendekatan sosial. Lingkup penelitian di Kampung Padang Kabupaten Selayar. Pada pembahasannya lebih pada alat tangkap dan interaksi masyarakat nelayan. Alat tangkap yang digunakan seperti Pasulo, Pabita, Pabubu, Papekang, dan Palanrak. Nelayan tradisional di Selayar bekerja secara individu. Pada tahun 1970an produksi ikan masih terbatas serta orientasi ekonominya bersifat subsistensi.

Berbeda halnya dengan nelayan di Desa Panaikang yang melaut pada saat itu yang tujuannya bukan hanya untuk 
memenuhi kebutuhan sehari-hari dalam keluarganya, tetapi juga untuk digunakan untuk membeli keperluan bahan pokok lainnya. Singkatnya, dapat dikatakan bahwa ciri ekonomi seperti ini bersifat non-profit oriented(Ahmadin, 2009). Nelayan di Desa Panaikang ini tidak bekerja perseorangan melainkan membentuk kelompok kerja berdasar atas kekeluargaan. Hal ini disebabkan oleh alat tangkap berupa payang (panja) membutuhkan banyak tenaga manual dalam penggunaannya.

Jadi, Desa Panaikang yang terletak di daerah pantai turut menjadikan sumber daya laut sebagai sumber penghidupan masyarakat pesisir, serta menentukan keadaan hidup sebagian masyarakatnya yang bermata pencaharian sebagai nelayan. Pada tahun 1955 merupakan awal mula aktivitas nelayan mencari ikan di laut dengan pola penangkapan yang masih bersifat tradisional. Nelayan di Desa Panaikang dijuluki sebagai nelayan pa'panja karena alat yang digunakan untuk menangkap ikan pada saat itu berupa payang (panja).

\section{Perkembangan Nelayan Tradisional di Desa Panaikang}

Nelayan tradisional ialah nelayan yang menggantungkan seluruh hidupnya dari kegiatan penangkapan ikan, dilakukan secara turun-temurun dengan menggunakan alat tangkap yang sederhana. Nelayan di Desa Panaikang pada fase 1955 dikenal sebagai nelayan tradisional (pa'panja). Papanja ialah julukan bagi nelayan tradisional pada saat itu dikarenakan oleh alat yang digunakan untuk menangkap ikan ialah panja. Panja adalah alat tangkap ikan menyerupai jaring berukuran besar dengan panjang sekitar 100 meter. Panja dikenal pula dengan sebutan jala loppo atau payang.

Payang adalah termasuk alat penangkapan ikan yang sudah lama dikenal nelayan Indonesia. Payang adalah pukat kantong yang digunakan untuk menangkap gerombolan ikan permukaan (pelagic fish). Payang merupakan jaring yang memiliki kantong dan dua buah sayap. Kedua sayapnya berguna untuk menakut-nakuti atau mengejutkan serta menggiring ikan untuk masuk kedalam kantong. Nelayan di Desa Panaikang memiliki kemampuan membuat alat tangkapnya sendiri berupa payang yang lebih dikenalnya dengan sebutan panja oleh penduduk setempat. Keterampilan ini merupakan hasil warisan turun temurun.

Adapun cara membuat payang (panja) seperti yang dikemukakan oleh H. Tulisi:

"Engka eddimai diaseng benna, to Buton maha. Iyaro diremme nappa dihakkasang, nappa di rakkoi, furai ro komarakkoni, dikerri pake ferring fura syahile, nappa diessoi si, ko marakkoni dituluni di foppang e. Lampe benna ta seddi metere. Ditulu ta maega, biasanna te mappattulu, mangolli tau. Nappa diebburang sojo, fering di ebbu, iyaro di senge ferring difue nappa di jai, nappa di ebbureng appang. Appang na fefeng atau ferring. Caka'na ta 30 reppa, 39 reppa lampe'na, 34 reppa aje sibawa boti. Batu ta 5, 2 diolo 2 dimunri silong 1 dicaka'na. Boti 9 metere lampe'na, lebbana ta 4 metere loangna.'(Tulisi, 2018)

Artinya:

"Dulu ada yang suatu benang yang dibawa oleh orang Buton. Benang itupun direndam lalu di tebar untuk dijemur. Setelah kering, diraut menggunakan bambu yang sudah di haluskan permukaannya. Kemudian dijemur kembali, dan setelah kering di buat tali pada paha. Panjang benang itu 1 meter dan proses pembuatannya kadangpula dibantu oleh orang lain. Kamudian dibuatkan alat penjahit yang terbuat dari bambu, lalu di jepit dan dijahit. Setelah itu, dibuatkan alat pengukur yang terbuat dari papan atau bambu. Bagian dinding payang berukuran 30 depa, panjang 39 depa, dan 34 depa pada bagian kaki dan kantong, serta menggunakan batu sebanyak 5. Kantongnya memiliki panjang 9 meter, dengan diameter lingkaran 4 meter."

Berdasarkan penjelasan dari H. Tulisi ini dapat dilihat banyaknya tahapan yang dilakukan untuk pembuatan payang (panja), sehingga proses pembuatannya memakan waktu kurang lebih 1 bulan. Payang (panja) 
juga terdiri dari beberapa bagian. Selain itu alat tangkap ini dapat di warnai dengan cara direndam menggunakan bahan dasar bakau sehingga menghasilkan warna coklat.

Penggunaan alat tangkap ikan berupa payang (panja) ialah dengan cara arah perahu yang terhenti, kemudian panja dibuang hingga melingkari gerombolan ikan lalu di tarik kearah perahu. Metode penangkapan dengan panja tidak dapat dilakukan secara individu atau sendiri. Sebab alat ini membutuhkan banyak orang atau tenaga untuk menebar dan menariknya. Kerja sama nelayan sangat diperlukan untuk mendapat hasil tangkapan yang maksimal. Biasanya nelayan terdiri dari 7-8 orang saat menebar panja menggunakan perahu biruang dan 10-12 orang saat menggunakan perahu pagatang dan soppek Bajo (soppe' bajo). Setiap orang memiliki tugas atau komponen sistem kerja yang diuraikan sebagai berikut:

Tabel 2.1 Komponen Sistem Kerja Nelayan Pa'panja di Desa Panaikang.

\begin{tabular}{|l|l|l|l|}
\hline $\begin{array}{l}\text { N } \\
\text { o }\end{array}$ & $\begin{array}{l}\text { Sistem } \\
\text { Kerja }\end{array}$ & Jumlah & \multicolumn{1}{|c|}{ Keterangan } \\
\hline 1 & $\begin{array}{l}\text { Ulu } \\
\text { balang }\end{array}$ & $\begin{array}{l}1-2 \\
\text { orang }\end{array}$ & $\begin{array}{l}\text { Menarik jangkar } \\
\text { guna menstabilkan } \\
\text { posisi perahu. }\end{array}$ \\
\hline 2 & $\begin{array}{l}\text { Juru } \\
\text { mudi }\end{array}$ & $\begin{array}{l}1 \\
\text { orang }\end{array}$ & $\begin{array}{l}\text { Mengemudikan } \\
\text { perahu. }\end{array}$ \\
\hline 3 & Kunrali & $\begin{array}{l}1 \\
\text { orang }\end{array}$ & $\begin{array}{l}\text { Menimba air yang } \\
\text { masuk ke dalam } \\
\text { perahu. }\end{array}$ \\
\hline 4 & $\begin{array}{l}\text { Pung } \\
\text { jala }\end{array}$ & $\begin{array}{l}2-4 \\
\text { orang }\end{array}$ & $\begin{array}{l}\text { Menarik payang } \\
\text { (panja). }\end{array}$ \\
\hline 5 & $\begin{array}{l}\text { Faccam } \\
\text { ming }\end{array}$ & $\begin{array}{l}2 \\
\text { orang }\end{array}$ & $\begin{array}{l}\text { Menyelam untuk } \\
\text { melihat ikan yang } \\
\text { ada di sekitar } \\
\text { payang (panja). }\end{array}$ \\
\hline 6 & $\begin{array}{l}\text { Fakolo } \\
\text { ng }\end{array}$ & $\begin{array}{l}1 \\
\text { orang }\end{array}$ & \begin{tabular}{l} 
Memasak. \\
\hline
\end{tabular} \\
\hline
\end{tabular}

Sumber: (Mustaming, 2018)

Tabel 2.1. diatas menunjukkan bahwa sistem kerja nelayan pa'panja di Desa Panaikang terdiri dari 6 bagian. Ada yang disebut ulu balang (penarik jangkar), juru mudi, kunrali (penimba air pada perahu), pung jala (penebar atau penarik panja), faccamming (penyelam), dan fakolong (tukang masak). Semua nelayan dalam satu perahu ikut bekerja tanpa terkecuali. Dan kegiatan saat menangkap ikan ini dilakukan secara bergantiaan saat menarik jangkar (balango) maupun pada saat menarik payang (panja).

Adapun jenis perahu yang di gunakan oleh nelayan tradisional di Desa Panaikang, antara lain:

\section{a. Perahu Bercadik (Lopi Biruang)}

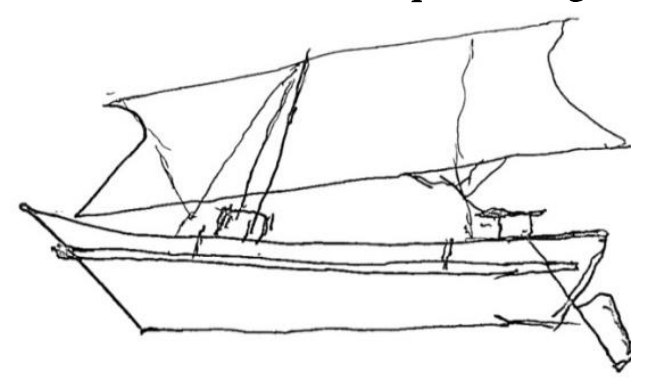

Gambar 1. Perahu Biruang

(Sumber: Digambar oleh Mustaming , 28 Juni 2018)

Sebelum terbentuknya Desa Panaikang, sekitar tahun 1955 setelah masa gorilla (DI/TII) di Kabupaten Sinjai, daerah ini pada saat itu masih dikenal sebagai kampung Baringeng. Nelayan di wilayah pesisir pantai menggunakan perahu yang disebut "lopi biruang". Perahu Biruang adalah jenis perahu nelayan dengan menggunakan dua alat penyeimbang yaitu masing-masing pada bagian kiri dan kanan sehingga keadaan perahu selalu seimbang dan tidak mudah tenggelam, kedua alat penyeimbang itu terbuat dari bambu yang diikat dan dihubungkan dengan perahu.

Ukuran perahu ini panjangnya 10 meter, lebar 1 meter, dan tingginya 1,5 meter. Selain lebih panjang, perahu jenis ini hanya menggunakan tenaga manual yakni tenaga manusia dengan cara mendayung (ma'bise). Selain itu perahu bercadik (lopi biruang) sudah menggunakan bantuan layar yang terbuat dari kain katun (balacu) sebagai alat gerak bantunya. Kapasitas perahu cukup 7-8 orang. Meski demikian wilayah penangkapan masih terbatas pada wilayah yang dekat dari pesisir pantai Baringeng, yakni di pesisir Pulau Burung Loe Kecamatan Pulau Sembilan Kabupaten Sinjai. Alat yang digunakan oleh 
nelayan yaitu payang (panja). Jenis ikan yang mereka tangkap berupa ikan kecil jenis teri. Adapun waktu penangkapan ikan berlangsung sekitar jam 3 subuh hingga jam 1 siang. (Tulisi, 2018)



Gambar 2. Perahu Biruang

(Sumber: Digambar oleh Mustaming , 28 Juni 2018)

Pada tahun 1960-an sistem pemerintahan Kampung Baringeng berubah menjadi Desa Panaikang yang mana pada tahun tersebut diangkatlah Puang Lanna sebagai Kepala Desa pertama. Masyarakat nelayan di Desa Panaikang pada fase 1960-an sudah tidak menggunakan lopi biruang lagi. Perahu yang mereka gunakan ialah "lopi pagatang". Lopi pagatang adalah jenis perahu tradisional dari wilayah Pagatang, yang memiliki ciri atau tanda berupa ornamen ukiran bunga pada bagian ujung depan perahu. Ukuran lopi pagatang ini panjangnya 10 meter, lebar 2 meter, dan tingginya kurang lebih 2 meter.(Mustaming, 2018)

Perahu tradisional yang mereka beli di Pagatang, Kalimantan Selatan ini digerakkan dengan bantuan tenaga manusia yakni menggunakan dayung. Cara mendayung pun mulai bervariasi, ada yang dengan cara ma'bise adapula dengan cara ma'gajong. Ma'bise adalah cara menggerakkan perahu dengan menggunakan dayung yang tidak terikat pada perahu, digunakan oleh masing masing orang. Dalam satu perahu nelayan yang ma'bise terdiri dari 6 orang menghadap ke kedepan yang posisinya di bagian belakang perahu. Sedangkan ma'gajong adalah cara menggerakkan perahu menggunakan dayung yang sudah terikat pada bagian tepi sisi kanan dan sisi kiri perahu, dilakukan oleh 2 orang yang duduk berdampingan. Alat ini degerakkan dengan cara menarik kayu atau ujung dayung (gajong) ke arah tubuh. Dalam satu perahu terdiri dari 4-6 orang yang duduk berdampingan menghadap ke belakang dengan posisi di bagian depan perahu. Selain itu perahu Pagatang sudah menggunakan bantuan layar yang terbuat dari kain katun (balacu) sebagai alat gerak bantunya. Kapasitas perahu cukup 10-12 orang.(Mustaming, 2018)

Nelayan tradisional di Desa Panaikang di kenal dengan sebutan pa'panja. Hal ini karena mereka menggunakan alat berupa payang (panja) untuk menangkap ikan di laut. Meski menggunakan alat berupa panja dan ukuran perahu yang masih terbilang sederhana. Namun pada tahun 1960 jangkauan operasional nelayan sudah mulai merambah ke wilayah yang cukup jauh dari pesisir Desa Panaikang. Bahkan meraka sampai di perairan luar Sulawesi seperti ke Tanjung Pandang dan Bangka.

Perjalanan menuju wilayah tersebut mereka tempuh selama satu bulan lamanya di laut lepas dengan mengikuti arah atau petunjuk kompas (fedomang), posisi matahari dan bulan. Keberanian mereka mempertaruhkan nyawa demi mencukupi kehidupan keluarganya. Semua tenaga dikerahkan untuk mendayung perahu saat angin tak mendukung untuk menggerakkan perahunya. Kadangpula pasrah saat terombang-ambing di laut mengikuti arah angin yang menempa layar pada perahu menuju arah yang sama sekali tidak diketahui. Tapi suatu kesyukuran karena tiba di tempat tujuan dengan selamat.(Mustaming, 2018)

Nelayan mencari ikan di pesisir Tanjung Pandang setiap hari dan mereka menetap disana dalam jangka waktu yang cukup lama pula. Semua nelayan yakni 12 orang tersebut dalam satu perahu ikut bersama-sama mencari ikan. Hal ini karena butuh orang banyak dan tenaga manual untuk menggunakan panja. Mereka biasanya memperoleh hasil tangkapan 
seperti ikan simbula (lincis), bau-bau (siu), dan ikan layang.

\section{c. Perahu Soppek (Soppe'Bajo)}



Gambar 3. Perahu Biruang

(Sumber: Digambar oleh Mustaming , 28 Juni 2018)

Pada tahun 1969 mulai ada nelayan di Desa Panaikang yang menggunakan perahu jenis soppe' bajo. Soppek ini memiliki panjang 9 meter, lebar 2,5 meter, dan tingginya 1,5 meter. Soppe' bajo adalah perahu dari suku Bajo menyerupai sampan yang kemudian ditambah dengan tiga atau empat keping papan. Perahu ini masih menggunakan alat bantu layar. Perahu ini di gunakan saat nelayan melaut ke tanjung pandang.(Tulisi, 2018)

Proses penangkapan ikan nelayan di desa Panaikang sebelum adanya modernisasi masih sangat sederhana. Mereka hanya mengandalkan ilmu atau keterampilan yang dipelajarinya secara turun-temurun. Mulai dari proses pembuatan payang dan penggunaanya, kegiatan melaut serta metode penangkapan ikan. Nelayan di Desa Panaikang pada masa tradisional belum mengenal pemakaian rompon, sehingga mereka hanya belajar dari pengalaman misalnya dengan mengamati perairan yang terdapat daun atau batang kelapa yang hanyut. Dari benda tersebut mereka dijadikan patokan bahwa di wilayah perairan tersebut terdapat gerombolan ikan.

Jadi, nelayan tradisional di Desa Panaikang setelah mengalami perkembangan lambat laun mulai merambah ke wilayah operasional yang cukup jauh meskipun masyarakat pesisir masih mengandalkan perahu yang ukurannya kecil yang digerakkan dengan tenaga manual yakni mendayung dan bantuan layar sehingga volume tangkapnya pun masih kecil. Terdapat komponen system kerja masing masing nelayan. Kelompok ini membutuhkan banyak tenaga bahkan hingga 12 orang sebab alat yang digunakan berupa payang (panja).

\section{Kehidupan Sosial Ekonomi dan Budaya Nelayan}

\section{a. Sosial}

Nelayan adalah orang yang hidupnya sangat tergantung pada biota laut. Laut merupakan tempat untuk mencari nafkah bagi seorang nelayan dan merupakan aktivitas yang sudah biasa mereka lakukan.(Alimuddin, 2004) Karena itu masyarakat nelayan diartikan sebagai orang atau manusia yang hidup bersama dalam waktu yang relatif lama, yang sadar bahwa mereka adalah satu kesatuan yang mempunyai pekerjaan atau mata pencaharian pokok menangkap ikan serta hasil laut lainnya.

Dalam hidup bermasyarakat tentunya ada hubungan sosial yang terjalin antar manusia yang satu dengan lainnya. Bahkan hubungan sosial itu berawal dari hubungan antara anak dan orang tuanya. Hingga muncul kesadaran akan berbagai keterbatasan yang dimiliki, kemudian menstimulasi untuk menjalin kerjasama.

Kelompok nelayan dapat dibedakan atas punggawa dan sawi. Punggawa terdiri atas punggawa besar, yang bertugas mengorganisir anggotanya, menyiapkan modal, memasarkan hasil produksi ikan dan pembagian hasil. Punggawa kecil bertugas membantu punggawa besar mengontrol sawi, sekaligus berkewajiban membimbing, menuntun, mengarahkan, dan mewariskan berbagai pengetahuan dan keterampilan.(Sallatang, 1982)

Berdasarkan karakteristik nelayan tersebut, maka nelayan tradisional di Desa Panaikang dapat dikelompokkan menjadi:

1. Nelayan yang memiliki sarana produksi baik dari segi perahu maupun alat tangkap berupa payang (panja) dan terlibat langsung dalam kegiatan menangkap ikan dilaut (punggawa).

2. Nelayan yang tidak mempunyai apaapa sehingga ikut bekerja pada 
punggawa sebagai nelayan buruh (saw).

Pola hubungan kerja masyarakat nelayan di Desa Panaikang sebelum modernisasi, tampaknya masih bersifat kekeluargaan. Kegiatan menangkap ikan nelayan yang dilakukan secara berkelompok dan terdiri dari punggawa dan sawi. Mereka masih dalam lingkup hubungan antara orang tua dan anak ataupun keluarga dekat lainnya, dan belum mengenal sistem kontrak kerja. Adapula nama-nama punggawa pada masa itu ialah Mustaming, H. Aminuddin, H. Tulisi, H. Abdul Karim, H. Sahibe, H. Fera, H. Dani, H. Saleh, H. Toeng, dan H. Kuta. Dari sepuluh nama punggawa tersebut, yang masih hidup tinggal 5 orang, yaitu Mustaming, H. Aminuddin, H. Tulisi, H. Abdul Karim, H. Sahibe sedangkan yang lainnya telah meninggal.

\section{b. Ekonomi}

Kondisi masyarakat nelayan di Desa Panaikang masih jauh dari tingkatan sejahtera. Kehidupan mereka sangat tergantung dari keadaan alam dan cuaca, tanpa bias mengatasi tantangan alam, karena peralatan mereka yang masih sangat tradisional yakni dengan memakai perahu layar dan alat tangkap ikan yang sederhana serta menguras banyak tenaga. Dengan demikian produksi juga tidak menunjukkan peningkatan yang berarti sehingga perekonomian masyarakat masih sangat rendah.

\section{Pemasaran}

Hasil yang diperoleh para nelayan berupa ikan adalah imbalan mereka terhadap upaya dan keikutsertaannya dalam kelompok kerja sebagai nelayan. Untuk mendapatkan hasil tersebut membutuhkan perjuangan dari nelayan dalam menghadapi segala resiko yang mungkin saja terjadi di lautan. Ikan yang dihasilkan itu kemudian dipasarkan atau dikenal dengan istilah distribusi.

Pemasaran ikan nelayan tradisisonal (pa'panja) di Desa Panaikang pada tahun 1955 dilakukan di tepi pantai. Nelayan memasarkan hasil tangkapannya secara langsung kepada papalele. Papalele adalah orang yang memusatkan perhatiannya pada usaha penyaluran barang hasil produksi nelayan berupa ikan ke penyalur berikutnya atau langsung ke konsumen. Untuk lebih jelasnya maka dapat dilihat pola distribusi sebagai berikut:

\section{Nelayan Papalele $\Rightarrow$ Konsumen}

Gambar 4. Pola Kegiatan Pemasaran Hasil

Tangkapan Ikan Nelayan Tradisional (pa'panja) di Desa Panaikang

Gambar 4. diatas menunjukkan pola pemasaran hasil tangkapan ikan nelayan tradisional (pa'panja) di Desa Panaikang yang dijual secara langsung kepada papalele (pedagang ikan). Papalele ini menunggu di sekitar bibir pantai dan menyambut kedatangan para nelayan yang hendak melaut. Mereka bukan penduduk dari Desa Panaikang melainkan papalele dari kampung lainnya seperti Babana, Pasahakue, dan Patalassang. Kemudian menyalurkan ikan hasil tangkapan nelayan tersebut kepada konsumen.

Pada tahun 1960 nelayan di Desa Panaikang sudah mengenal sistem pasar. Nelayan biasanya menjual ikan di pasar toae (tua) atau pasar Baringeng dan jika ada ikan atau hasil tangkapan yang tidak laku, maka ikan dibawa pulang kerumah kemudian dijemur. Biasanya para pedagang ikan dari wilayah Manimpahoi Kecamatan Sinjai Tengah yang datang membeli ikan kering tersebut. Saat melaut ke daerah Tanjung Pandang dan Bangka, pemasaran ikan dilakukan dengan sistem pasar. Nelayan terjung langsung menjual ikannya dipasar tradisional di daerah itu.

\section{Sistem Bagi Hasil}

Pola penangkapan ikan yang dilakukan secara berkelompok berdasarkan kekeluargaan ini sehingga sistem bagi hasil tidak terlampau jauh perbandingannya antara satu sama lain. Sistem bagi hasil didasarkan pada kepemilikan perahu, alat tangkap dan keikutsertaan melaut. Adapun sistem bagi hasilnya dapat diuraikan sebagai berikut: 
a. Pemilik perahu (punggawa) : 2 bagian

b. Pemilik payang (panja) : 1 bagian

c. Nelayan yang ikut melaut (sawi) : 1 bagian(Tulisi, 2018)

Nelayan di Desa Panaikang umumnya jika dia merupakan punggawa pasti memiliki perahu dan alat tangkap berupa panja sehingga mendapat 3 bagian. Nelayan sawi yang ikut melaut serta memiliki panja maka mendapat 2 bagian, sedangkan sawi yang tidak memiliki panja hanya mendapat 1 bagian saja.

\section{c. Budaya}

Nelayan adalah salah satu unsur masyarakat dengan budaya yang telah tumbuh dan mengakar dalam diri dan kehidupan masyarakat pada masanya. Budaya tersebut dalam kebiasaan atau tradisi yang sering dilakukan yang sangat erat kaitannya dengan kepercayaan dan pengetahuan yang dimiliki oleh para nelayan. Tradisi yang bersifat sakral dengan pola tingkah laku yang mengandung nilainilai dan tata cara yang harus dipedomani dengan nilai tertentu. Pada tahun 1960-an budaya masih dijunjunng tinggi oleh masyarakat nelayan karena dalam pandangan masayarakat pada masa itu tradisi seperti itu dapat mendatangkan berkah dan keselamatan.

Ritual nelayan tidak berdiri sendiri, tetapi terkait dengan keyakinan, pengetahuan, pengalaman (realitas), dan kondisi kejiwaan (spritualitas). Semua itu dikategorikan sebagai unsur-unsur yang masuk pada ranah religiusitas. Karenanya teori-teori religi sangat relevan dikemukakan sebagai salah satu elan vital pengkajian dalam rangka memahami praktik-praktik ritual nelayan.(Arifuddin Ismail, 2012)

Taylor menyebutkan, kelakuan manusia yang bersifat religi berawal dari adanya kesadaran akan adanya jiwa. Evolusi religi pada manusia diawali dari kepercayaan bahwa yang menempati alam sekeliling manusia adalah makhlukmakhluk halus yang tidak tertangkap oleh pancaindra. Makhluk halus dianggap mampu berbuat hal-hal yang tidak dapat dilakukan manusia. Anggapan seperti itu yang menjadikan manusia memposisikan makhluk halus sebagai objek penghormatan dan penyembahan dalam berbagai bentuk upacara, doa, sajian dan sebagainya.(Arifuddin Ismail, 2012)

Berdasarkan pada teori yang telah dikemukan oleh Taylor, maka hal yang menarik dari nelayan di Desa Panaikang pada saat menggunakan alat tangkap berupa panja ialah adanya larangan untuk bercerita tentang hal yang diaggap buruk sebelum melaut. Misalnya berupa larangan menyebut nama hewan tertentu yang sebenarnya melainkan harus disamarkan seperti saat menyebutkan kucing maka hal itu diganti dengan menyebut kata "tedafuru", dan kuda dengan sebutan "tettere".(Mustaming, 2018) Hal tersebut dipercaya oleh nelayan bahwa itu dapat berdampak buruk pula pada hasil tangkapan mereka. Sehingga punggawa biasanya memukul kepala nelayan sawi jika ada yang menyebut nama hewan secara langsung ketika berada di tengah laut.

Selain itu terdapat budaya berupa tradisi selamatan yang dilakukan oleh punggawa saat hendak melaut, seperti yang dikemukakan oleh Sakka selaku istri nelayan bahwa saat akan melaut, ada tradisi yang dilakukan dengan cara menumbuk kemiri dengan kapas untuk membuat alat penerang semacam lilin yang disebut sulo fesse. Sulo fesse ini disimpan didekat panja yang telah disimpan diatas daun lahira (menyerupai daun talas) sebelum di angkat ke perahu. Payang (panja) yang nyala apinya besar dan terang maka itu yang pertama kali dibawa ke perahu dan akan digunakan lebih dahulu nantinya saat menangkap ikan. Hal ini diyakini akan menghasilkan ikan yang lebih banyak, sebab nelayan biasanya membawa lebih dari 2 panja saat hendak melaut. Acara selamatan juga telah disediakan makanan atau sajian berupa tumbu' dan baje. Selain itu dijelaskan pula bahwa penduduk sekitar datang berbondong bondong ke rumah punggawa yang akan melaut.(Sakka, 2018) Kedatangan mereka untuk membantu 
persiapan nelayan tersebut serta menghadiri acara selamatan sebagai rasa syukur dan harapan doa keselamatan bagi mereka yang akan melaut.

Jadi, kegiatan menangkap ikan nelayan dilakukan secara berkelompok dan terdiri dari punggawa dan sawi. Terjalin kerja sama antar nelayan dan ikatan yang terbentuk ialah sistem kekeluargaan dan kekerabatan.Serta orientasi penangkapan ikan masih bersifat subsisten. Kondisi ekonomi masyarakat di Desa Panaikang yang berkerja sebagai nelayan masih belum sejahtera. Selain itu, terdapat sebuah tradisi berupa acara selamatan yang dilakukan oleh nelayan saat hendak melaut. Budaya ini pula dianggap dapat mempengaruhi tingkat penghasilan nelayan.

\section{E. Kesimpulan}

Nelayan tradisional di Desa Panaikang di kenal sebagai nelayan pa'panja karena alat tangkap ikan yang digunakan berupa payang (panja). Keberadaan nelayan ditandai dengan maraknya aktivitas nelayan mencari ikan di laut sejak tahun 1955 untuk memenuhi kebutuhan hidup keluarganya. Kehidupan nelayan tradisional (pa'panja) awalnya dengan pola kegiatan produksi atau kegiatan penangkapan tidak jauh dari garis pantai karena keterbatasan yang dialami. Meski dengan keterbatasan tersebut, nelayan tradisional melakukan penetrasi dengan perkembangannya yang lambat laun mulai merambah ke wilayah operasional yang cukup jauh yakni ke Tanjung Pandang dan Bangka, meskipun masyarakat pesisir masih mengandalkan perahu yang ukurannya kecil yang digerakkan dengan cara mendayung dan bantuan layar sehingga volume tangkapnya pun masih kecil. Kegiatan menangkap ikan nelayan dilakukan secara berkelompok dan terdiri dari punggawa dan sawi. Terjalin kerja sama antar nelayan dan ikatan yang terbentuk ialah sistem kekeluargaan dan kekerabatan.Serta orientasi penangkapan ikan masih bersifat subsisten. Kondisi masyarakat nelayan di Desa Panaikang masih belum sejahtera. Selain itu, terdapat sebuah tradisi berupa acara selamatan yang dilakukan oleh nelayan saat hendak melaut yang dianggap oleh nelayan dapat berpengaruh terhadap hasil tangkapan.

\section{DAFTAR PUSTAKA}

Tim Penyusun Pusat Kamus. (2007). KBBI (Kamus Besar Bahasa Indonesia) (Ketiga ed.). Jakarta: Balai Pustaka. Ahmadin. (2009). Nelayan Tradisional dan Modernisasi: Potret Masyarakat Pesisir di Pulau Selayar. Makassar: Rayhan Intermedia.

Alimuddin, M. R. (2004). Mengapa Kita Belum Cinta Laut. Yogyakarta : Ombak.

Arifuddin Ismail. (2012). Agama Nelayan. Yogyakarta: Pustaka Pelajar.

BPS. (2015). Kabupaten Sinjai Dalam Angka.

Endang Retnowati. (2011). Nelayan Indonesia Dalam Pusaran Kemiskinan Struktural. Perspektif.

Hariyono. (1995). Mempelajari Sejarah Secara Efektif. Malang: Pustaka Jaya.

Ida Bagoes Mantra. (2000). Demografi Umum. Yogyakarta: Pustaka Pelajar.

Kuntowijoyo. (2005). Pengantar Ilmu Sejarah. Yogyakarta: Bentang.

Kusnadi. (2003). Akar Kemiskinan Nelayan. Yogyakarta: Lkis.

Mayor Polak. (1976). Sosiologi Suatu Pengantar Ringkasan Ikhtisari. Jakarta: Ichtiar Baru.

Mustaming. (2018, Maret 15). Nelayan Tradisional di Desa Panaikang.

Profil Desa Panaikang. (2017). Buku Profil Desa Panaikang Tahun 2015. Sinjai.

Rustam Tamburaka. (1999). Pengantar Ilmu Sejarah, Teori Filsafat Sejarah, Sejarah Filsafat dan Iptek. Jakarta: Rineka Cipta.

Sakka. (2018, Maret 15). Budaya Nelayan di Desa Panaikang.

Sallatang, A. (1982). Pinggawa-Sawi: suatu studi Sosiologi Kelompok Kecil. Ujungpandang: PPs-UNHAS. 
Sugeng Priyadi. (2012). Metode Penelitian

Pendidikan Sejarah. Yogyakarta:

Ombak.

Tulisi, H. (2018, Maret 19). Kehidupan

Nelayan Tradisional di Desa

Panaikang. 